\title{
'N AANGEPASTE BEWUSTHEIDSPROGRAM OM FONOLOGIESE EN FONEMIESE BEWUSTHEID IN AANVANGSLEES VAN GRAAD 1-LEERDERS IN 'N TAALARM OMGEWING TE VERBETER
}

Patricia J. Marthinussen

Universiteit van Stellenbosch

Michele F. van der Merwe

Universiteit van Stellenbosch

Die rol van fonologiese en fonemiese bewustheid en die verstaan van letterklankkorrespondering in aanvangslees in 'n graad 1-klas word in die artikel beklemtoon. Die vermoë van leerders om ouditiewe en visuele persepsies, asook onderskeidingsvermoë tussen klanke en klankpatrone te ontwikkel, word as voorspellers vir suksesvolle lees beskryf. Vroeë en deurlopende assessering van aanvangsleesvaardighede is 'n belangrike aspek om die voorkoming van leesuitvalle te bewerkstellig. 'n Intervensieprogram om die fonologiese en fonemiese bewustheid van leerders te verbeter, word beskryf. Die navorsingsmetodes, insluitende voor-en natoetse word beskryf. Navorsing is in 'n graad 1-klas uitgevoer met leerders wat geen graad $R$-onderrig ontvang het nie en op die ouderdom van $5^{1 / 2}$ jaar reeds by die skool ingeskryf is. Die leerders is jonk en ontvang nie genoegsame stimulering tuis nie. Hulle toon reeds agterstande in effektiewe taalgebruik en hoe om aandag te gee en te leer by skooltoetrede. Hierdie agterstande noop die navorsers om te fokus op die fonologiese en fonemiese bewustheid in aanvangslees van die jong kind.

Trefwoorde: fonologiese bewustheid, fonemiese bewustheid, aanvangslees en intervensie

\section{An adjusted programme to improve phonological and phonemic awareness in early reading of Grade 1 learners in a language-poor environment}

The role of phonological and phonemic awareness, as well as the understanding of syllablesound correspondence in early reading in a grade 1 class is foregrounded in the article. The ability of learners to develop auditive and visual perception, as well as the ability to distinguish between sounds and sound patterns is described as precursors for successful reading. Early and continuous assessment of early reading skills could play a major role in the prevention of reading backlogs. An intervention programme to increase the phonological and phonemic awareness of learners is described. The research methods, including pre-tests and post-tests, are described in the article. Research was conducted in a grade 1 class on learners who did not receive grade $\mathrm{R}$ education and who were already enrolled at the age of five and a half years at the school. The learners are young and do not receive sufficient stimulation at home. They lack behind in effective language usage, attention span and learning ability at school. These backlogs prompted the researchers to focus on the role of phonological and phonemic awareness in early reading skills of the young child.

Key words: phonological awareness, phonemic awareness, early reading and intervention. 


\section{INLEIDING}

Die klem in hierdie artikel val op die effektiewe gebruik van 'n fonologiese en fonemiese aangepaste bewustheidsprogram om die beginnerleser in aanvangslees te ondersteun om die nodige leessukses in latere formele leesonderrig te bemeester, aangesien Warmington en Hulme (2012) daarop wys dat fonemiese bewustheid een van die kritiese bepalers is vir wanneer leerders leer om te lees. Die belangrikheid van blootstelling van die kind aan onderrig in graad $\mathrm{R}$ en die invloed wat die stimulering en voorbereiding op hierdie kind in graad 1 het, word beklemtoon.

Die swak geletterdheidsuitslae van jaarlikse sistemiese toetse deur die Wes-Kaapse Onderwysdepartement (WKOD), graad 1-3 by 'n landelike skool in die Kaapse Wynland Onderwysdistrik het ons belangstelling in hierdie onderwerp geprikkel. Leerders in die teikengroep woon in 'n landelike omgewing, is hoofsaaklik kinders van plaaswerkers en bevind hul in 'n lae sosio-ekonomiese milieu. Die armoede waarin die kinders hulle bevind, is 'n groot struikelblok vir die ontwikkeling van hulle volle potensiaal. Die omgewing waarin die kinders hul bevind, is nie gunstig vir die ontwikkeling van taal nie, omdat die ouers nie in staat is om die nodige leesmateriaal en opvoedkundige ondersteuningsmateriaal aan te koop nie.

\section{LITERATUURSTUDIE}

Volgens Venter (2007: 91) verwys fonologiese bewustheid na die vermoë om op 'n eksplisiete wyse aandag aan die fonologiese struktuur van die gesproke woord te gee en te verstaan dat die gesproke taal uit kleiner individuele klanke bestaan. Vir Ericson en Juliebö (2000: 4) is fonologiese bewustheid 'n metalinguistieke vaardigheid wat leerders toelaat om te reflekteer oor kenmerke van gesproke taal (Griffith, Klesius en Kromrey, 1992). Phillips, Menchetti en Lonigan (2008: 1) beskou fonologiese bewustheid as een van die sleutelvoorlopers om leesvaardigheid in die voorskoolse fase van die leerder te ontwikkel.

Demont en Crombert, (1996: 315) beweer dat fonologiese bewussyn 'n voorwaarde vir leessukses is. Die leser moet fonologiese vaardighede aanleer wat hom in staat stel om die gesproke woord in toepaslike fonologiese segmente te kan opbreek. Die leerder moet tydens geletterdheidsgereedmaking, bewus gemaak word van die fonologiese struktuur van taal. Die vermoë om woorde te analiseer in fonemiese segmente en om oor voldoende fonologiese strategieë en vaardighede te beskik, speel 'n beduidende rol in latere leesprestasie. Goeie fonologiese bewussyn is een van die faktore wat tot die vorming van 'n positiewe ingesteldheid ten opsigte van lees bydra.

Volgens Yopp en Yopp (2000: 130) is fonemiese bewustheid 'a sensitivity to and control over phonemes'. Die onderrig in fonemiese bewustheid impliseer dus nie net onderrig in foneemgrafeem-verbande nie, maar dit is ook 'n bewusmaking van taal- en klankstrukture (Snider, 1995: 443).

Die term foneem word deur taalkundiges gebruik wanneer daar verwys word na die kleinste eenheid van spraak wat 'n sein na 'n luisteraar stuur wat die verskil in die betekenis van die taal ken. Om te onderskei tussen foneme, gebruik 'n spreker kategorieë wat in die brein opgestel is wanneer 'n taal bemeester word. Wanneer daar onderskeid tussen klanke getref word, word fisiese eienskappe van spraak geïdentifiseer. Foneme mag klanke insluit, 
alhoewel klanke in fonemiese kategorieë verskil in uitspraak en eienskappe, ontvang die spreker/luisteraar dit as dieselfde foneem. Die beginklank in 'stop' en 'skop' word verskillend uitgespreek, dit is twee verskillende klanke (Linnea, Ehri \& Nunes, 2004). Venter (2007: 91) verwys na die bevinding van die National Reading Panel (2002: 1-2) dat dit vir die verwerwing van leesvaardighede, noodsaaklik is dat die kind leer om foneme in woorde te manipuleer. Hierdie bevinding is geldig vir 'n verskeidenheid onderrigsituasies en 'n verskeidenheid leerders - ongeag die kinders se ouderdomme en graadvlakke. Die gevolgtrekking is dat kinders wat fonemiese bewustheid aangeleer het, beduidend beter lees as kinders wat onderrig ontvang het sonder dat enige aandag aan fonemiese bewustheid geskenk is. Ontwikkeling van fonemiese bewustheid het 'n beduidende uitwerking getoon op lees- en spelontwikkeling, en leerders met uiteenlopende vermoëns het 'n verbetering in leesvaardighede getoon (National Reading Panel 2002: 1-2).

Kinders wat graad 1 met 'n hoë peil van fonemiese bewustheid begin, vaar goed ongeag die tipe onderrig wat hulle ontvang. Warmington en Hulme (2012: 45) beskou goedgespesifiseerde fonemiese weergawes as een van die kritiese bepalers van hoe maklik kinders sal begin lees. Swak lesers sonder fonemiese bewustheid bly swak lesers, aangesien hul swak fonemiese bewustheid lei tot swak verwerwing van woordherkenningsvaardighede. Lees word verhinder, want probleme met kodering en woordherkenningsprosesse vereis te veel kognitiewe energie. Minder kognitiewe bronne is dus beskikbaar om hoë-vlak kognitiewe denke van integrasie en begrip te bewerkstellig. Kinders wat vinnige dekoderingsprosesse baasraak, verbind letters outomaties om woorde te vorm en kan aandag gee aan betekenis. Hulle lees meer, kry meer oefening en gevolglik verbeter lees. Die goeie leser se woordherkenningsproses is so outomaties en vinnig dat hulle nie aangewese is op konteks vir inligting nie. Hulle het dus nie nodig om op konteks te fokus nie. Begrip misluk dus nie omdat daar staatgemaak word op dekodering nie, maar as gevolg van dekoderingsvaardighede wat nie genoeg ontwikkel is nie (Stanovich 1993: 283). Fonologiese vaardighede wat kinders spontaan verwerf en dus reeds aan die begin van graad 1 besit en die vaardighede van foneembewussyn wat deur formele onderrig verwerf word, speel 'n belangrike rol in die kind se leessukses.

Lees is 'n moeilike vaardigheid vir sommige leerders om te bemeester, omdat dit nie in fisiese grense gemerk is nie (Adams, 1990). ' $\mathrm{n}$ Voorbeeld is die woord kat wat as een klankeenheid gehoor word in plaas van drie aparte klanke. Nog 'n voorbeeld is die identifisering van woorde met begin- en eindklanke in 'n woord soos hond. Dit is dus belangrik om vas te stel of die leerder die klankstruktuur van die taal verstaan.

Ericson en Joliebö (2000: 6) verwys na die verskillende assesseringsaktiwiteite wat opvoeders kan gebruik om die vlak van fonologiese bewustheid te bepaal. Yopp en Yopp (2000) gebruik die volgende vrae om leerders te assesseer:

- Woord-klankassossiasie, byvoorbeeld: Is daar 'n [k] in bok?

- Woord tot woordbypassing, byvoorbeeld: Begin kat en kas met dieselfde klank?

- Herkenning van rymproduksie: Woorde wat amper klink soos, kos, los, mos, bos, pos, klos

- Foneemsegmentasie, byvoorbeeld /b-a-k/

- Foneemtelling, byvoorbeeld: Die woord bak bestaan uit drie foneme

- Foneemsamevoeging, byvoorbeeld: Kan die leerder foneme saamvoeg om 'n woord te vorm? [b]...[œs]=bus

- Foneemweglating, byvoorbeeld: Sê mot, maar moenie die [m] sê nie $=[\mathrm{t} t]$ en

Per Linguam 2015 31(2):53-78

http://dx.doi.org/10.5785/31-2-613 
- Foneemomkering, byvoorbeeld: Sê som, maar keer die foneme om, mos.

Hierdie assesseringsaktiwiteite speel 'n belangrike rol in die bepaling van die leerder se vlak van ontwikkeling. Assessering van fonologiese bewustheid in die klaskamer kan help met die vroeë identifisering van risiko-leerders vir lees en spelling.

Leerders behoort in staat te wees om na hul eerste jaar in die Grondslagfase rympies te genereer, klankgrepe te identifiseer en woorde in klankgrepe op te deel. Hulle kan ook die aanvanklike klankgreep wegneem van 'n meerlettergrepige woord, soos byvoorbeeld kameelperd, waar hul slegs die woord kameel of perd of meel kan identifiseer (Liberman, Shankweiler, Fischer en Carter,1974; Stanovich, Cunningham en Cramer,1984; Yopp en Yopp, 2000). Studies toon aan dat deeglike onderrig die vlak van fonologiese bewustheid kan verhoog (Bradley en Bryant, 1985). Fonologiese bewussyn is die vermoë om klank- en taalsensitiwiteit aan te kweek en kan 'n lewenslange positiewe leesingesteldheid vorm. Griffith, Klesius en Kromerey (1992) het bevind dat die vlak van fonologiese bewustheid wat 'n kind in die begin van graad 1 besit, belangriker is as die soort onderrig in tradisionele basale of heeltaalbenadering wat leerders ontvang.

Leerders wat fonologiese bewustheid ontwikkel, herken op ouditiewe vlak dat woorde kan rym, op dieselfde klank begin of eindig en dat dit saamgestel is uit foneme (klanke) wat gemanipuleer kan word om nuwe woorde te vorm. Dit omsluit die latere ontwikkelingsvaardighede wat die leerder konstant laat reflekteer en klanke laat manipuleer om nuwe woorde te ontwikkel, soos die letters in kam kan herrangskik word om 'n nuwe, woord mak, te vorm (Stahl, 1992).

Volgens Joubert, Bester en Meyer (2006: 90) verskil navorsers ten opsigte van die suksesvolsste leesmetode. Die suksesvolle fasilitering van lees hang af van die kreatiewe toepassing van individuele leesmetodes of benaderings of die kombinasie daarvan, afhangende van die behoefte van die leerder. Leesbenaderings of leesmetodes kan onder twee hoofbenaderings gegroepeer word, naamlik die dele-na-die-geheelbenadering (bottom up) en die geheel-na-die-dele-benadering (top down). In die dele-na-die-geheel-benadering, ook bekend as die 'vaardigheidsverwerwingsteorie,' val die klem op die ontwikkeling van subvaardighede wat fokus op die geleidelike verwerwing van die oënskynlik komplekse leesvaardigheid. In die geheel-na-die-dele-benadering, ook bekend as die 'singewingsteorie', is die uitgangspunt dat daar deur lees 'n betekenisvolle geheel vorm, waar betekenis en sin die grondslag lê. Hierdie benadering is onderskeidelik verteenwoordigend van behavioristiese en psigolinguistiese denkskole (Joubert et al., 2006: 90).

Botha (2008: 4) beskou die gebalanseerde benadering tot geletterdheidsontwikkeling as 'n program waarin verskillende onderrig- en leer-metodologieë, elk met 'n spesifieke doel, gebruik word. Die metodologieë sluit in: gedeelde lees, gedeelde skryf, woord en sinsvlakwerk, groeplees, begeleide lees, onafhanklike lees, onafhanklike skryf, hardop lees, lees vir genot en stillees. Hierdie metodes word aanbeveel deur die Departement van Basiese Onderwys se Grondslag vir Leer-veldtog (2008-2011) en Nasionale Kurrikulum-en Assesseringsbeleidsverklaring (NKABV) (2011: 14-23.) 'n Gebalanseerde taalbenadering kan by alle tale geïmplimenteer word en word dus geïntegreerd benader.

Die navorsing in hierdie artikel is onderneem binne die teorie van sosiale konstruktivisme soos deur die teorieë van Mercer (1997), Vygotsky (1978) en Bandura (1997) weerspieël. 
Vygotsky (1978) gaan van die standpunt uit dat die ontwikkeling van leerders se kennis en begrip gevorm word deur die interaksie en verhoudings met ander - beide die portuurgroep en volwassenes. Die leerder tree op as 'n konstruktivis van sy eie kennis. Bandura (1997) verwys na die leerteorie van die sosiale omgewing as ' $n$ proses van waarneming in die leerproses. Bandura glo dat die kind ' $n$ aktiewe wese is wat inligting verwerk deur na te dink oor die verhouding tussen gedrag en gevolge. Leer deur waarneming kan nie sonder kognitiewe prosesse gebeur nie (McLeod, 2011). Die ideaal is dus om so te onderrig dat alle leerstyle geïnkorporeer word en dat die leerders gelei word om ook die areas van leer wat hulle nie normaalweg verkies nie, te ontwikkel. Deur na die verskillende leerstyle in die onderrigproses van leer om te lees te verwys, is daar 'n duidelike verband tussen leerstyle en onderrigstrategieë. Navorsing toon aan dat kinders op verskillende wyses leer. In hierdie studie is dit belangrik om te verwys na die ouditiewe leerder, visuele leerder en kinestetiese leerder. Sommige kinders vind dit beter om 'n visuele voorstelling, byvoorbeeld 'n prent, te sien om te onthou wat hy leer. Ander leer beter deur te luister, terwyl sommige kinders objekte sensories ervaar om te leer (Joubert et al., 2006: 2). Dit is dus belangrik dat daar in die beplanning van die leesproses vir onderrig en leer voorsiening gemaak moet word vir al die behoeftes van leerders in die klaskamer.

\section{DOELWIT VAN DIE STUDIE, NAVORSINGSVRAE EN -ONTWERP}

Die hoofdoel van hierdie studie is om navorsing te doen om te ondersoek hoe die geletterdheidsvlak van leerders verbeter kan word. Deur die program, "Ontvanklik vir klanke vir graad R" (Pepler, 2005) kon die navorser 'n aanduiding kry van die moontlikhede van die ontwikkeling van luistervaardighede. Die program is ontwikkel vir graad R-leerders en dit is aangepas om op graad 1- leerders se vlak te onderrig. Hierdie aangepaste program dien as riglyn vir die onderrig van fonologiese en fonemiese bewustheid. In die studie word gepoog om vas te stel of 'n intervensieprogram van fonologiese bewustheid, fonemiese bewustheid en letter-klankkorrespondering die geletterdheidsvlak van graad 1-leerders kan verbeter.

Die volgende meer gerigte vrae, word ondersoek:

Hoe behoort 'n effektiewe fonologiese en fonemiese program in 'n graad 1-klas toegepas te word?

Kan fonologiese en fonemiese bewustheid 'n positiewe bydrae lewer tot leessukses by beginnerlesers?

Fonologiese en fonemiese bewustheid, asook letter-klankkorrespondering, kan 'n verskil in die leessukses by aanvanglesers uit 'n taalarm omgewing bewerkstellig. Hiervoor is eksplisiete onderrig van fonologiese en fonemiese bewustheid noodsaaklik voordat die graad 1-leerder aan formele leesonderrig blootgestel word. Die NKABV verwys na die onderrig van Fonemiese bewustheid, Klanke en Woordherkenning (DvBO, 2011: 18).

'n Verteenwoordigende groep van dertien leerders in 'n Afrikaanssprekende graad 1-klas van een skool in 'n landelike omgewing in die Kaapse Wynlanddistrik is vir die navorsingstudie gekies. Die nodige etiese klaring is vir die navorsing verkry. Daar is geen kontrolegroep in die studie nie, aangesien die navorsing by ' $n$ landelike skool met ' $n$ klein klasgroep onderneem is. Die hele klasgroep is as proefgroep gebruik. Die leerders se ouderdomme 
wissel tussen vyf jaar en ses maande tot vyf jaar en nege maande. Hierdie groep leerders het geen blootstelling aan graad R-onderrig gehad nie en het dus geen stimulasie ter voorbereiding vir formele onderrig in graad 1 gehad nie. Hierdie groep leerders beskik ook oor geen agtergrond rakende die fonologiese en fonemiese bewustheid wat alreeds in graad $\mathrm{R}$ ontwikkel behoort te wees nie.

'n Voortoets, saamgestel deur Weskus-Wynland Onderwys Bestuur en Ontwikkeling Sentrum (OBOS) wat vir hierdie studie aangepas is, is aan die groep gegee. 'n Intervensieprogram vir graad 1- leerders is ontwikkel en aangebied. Na afloop van die intervensieprogram is 'n natoets soortgelyk aan die voortoets aan die proefgroep gegee. Veldnotas is geneem deur die navorser met behulp van 'n video-opname en observasie is tydens die intervensieprogram gedoen. ' $n$ Tweede fase waarin fonemiese bewustheid en letter-klankkorrespondering toegepas is, is gevolg. 'n Voortoets, intervensieprogram en natoets is met die proefgroep gedoen. 'n Vertaalde Yopp-Singertoets vir die toetsing van fonemiese bewustheid is deur leerders afgelê.

'n Informele voortoets is uitgevoer om te bepaal op watter vlak die leerders se begrip van fonologiese en fonemiese bewustheid is. In fase een is 'n proefgroep van dertien leerders vir 'n tydperk van ses weke onderrig. Hulle is onderrig volgens 'n bestaande fonologiese program met die fokus op ouditiewe persepsie, asook 'n geïntegreerde fonemiese program wat vir graad R ontwikkel is. Hierdie program is drie dae per week in die eerste 15 minute van die geletterdheidsperiode in groepsverband in ' $\mathrm{n}$ aparte klas, gevolg.

Dieselfde prosedure soos by fonologiese bewustheid is in fase twee met dieselfde proefgroep as fase een gevolg tydens die intervensieprogram vir fonemiese bewustheid en letterklankkorrespondering. 'n Toets wat as 'n natoets ontwikkel is, is aan proefpersone gegee om vas te stel of die gewenste resultaat bereik is. Die observasie-metode is gebruik om die begrip van fonologiese en fonemiese bewustheid, asook die reaksie by die leerders, waar te neem.

Aan die einde van die ses weke het die proefgroep 'n gestruktureerde natoets in die vorm van 'n vraelys ontvang om te bepaal of fonologiese bewustheid deur die proefgroep bemeester is. Proefpersone se reaksie is waargeneem en aangeteken en veldnotas is bygehou. Dit het die notering, refleksie, interpretasie en waarneming wat van die agtergrond van die aksienavorsingsomgewing afhanklik was, vergemaklik.

\section{INTERVENSIEPROGRAM}

Grové et al. (1992: 27) se werk wat as riglyn dien in die voorskoolse kurrikulum in SuidAfrika en die program deur Pepler (2005) is vir hierdie studie gebruik, omdat dit aan die kriteria van fonologiese en fonemiese bewustheid in die NKABV voldoen. Die program is individueel deur verbale instruksies en skriftelike aktiwiteite wat luistervaardighede insluit, gevolg. Sien bylaag $\mathrm{C}$ in hierdie verband.

\section{VOORTOETS VIR FONOLOGIESE BEWUSTHEID}

Die volgende is bevind tydens die voortoets:

1. Ouditiewe syfergeheue (syfergeheue word ingesluit, aangesien dit deel vorm van die toets van luistervaardighede): Die getalgroepe wissel van driesyfergetalle tot vyfsyfergetalle. 
Die driesyfergetalle is deur elf proefpersone korrek weergee en twee kon dit nie bemeester nie. Die viersyfergetalle is deur twaalf proefpersone korrek weergee met slegs een uitval. Uit die vyfsyfergetalle kon slegs drie uit die dertien proefpersone die korrekte antwoorde weergee en tien het uitvalle getoon. Dit het voorgekom asof die syfergeheue van die proefpersone nie sulke groot uitvalle tydens die toets toon nie, maar hoe groter die getalgroep geword het, hoe meer het proefpersone groter uitvalle getoon. Elf proefpersone het $50 \%$ korrekte antwoorde gegee terwyl slegs een proefpersoon $100 \%$ en een proefpersoon geen punte in hierdie afdeling behaal het.

2. Ouditiewe woordgeheue (verwante woorde): In die groep verwante woorde met drie woorde kon twee proefpersone die woorde weergee. Die ander elf proefpersone kon nie die woorde weergee nie. In die vier-groep verwante woorde kon drie proefpersone die antwoode korrek weergee en tien kon nie die antwoorde weergee nie. Uit die vyf-groep verwante woorde kon drie proefpersone die antwoorde korrek weergee en tien uit die dertien toon uitvalle. In hierdie afdeling kon twee proefpersone al drie antwoorde korrek weergee en elf proefpersone toon groot uitvalle.

3. Ouditiewe diskriminasie: Uit 'n groep van vier woorde waarvan twee van die woorde dieselfde is, kon geen van die dertien proefpersone die woorde wat dieselfde is, weergee nie.

4. Rym: Uit 'n groep van vyf woorde waar die proefpersoon die woord wat nie rym nie, moes identifiseer, was nie een van die proefpersone in staat om die woord weer te gee nie.

Uit 'n groep van drie woorde moes proefpersone drie woorde noem wat klink soos die woorde in die groep. Uit die dertien proefpersone kon geen proefpersone woorde wat dieselfde klink, weergee nie.

\section{Ouditiewe analise:}

- Identifiseer eerste, laaste, middelste klanke: Proefpersone het 'n groep van drie woorde gekry waarvan die eerste, laaste en middelste klank aangedui moes word, byvoorbeeld kop, mes, rok. Uit 'n totaal van dertien kon geen proefpersoon die komponent voltooi nie.

- Woorddele wegneem: Proefpersone kry een woord, byvoorbeeld waslap waarvan die een deel van die woord weggeneem word, byvoorbeeld 'was' of 'lap' In hierdie toets kon geen leerder die korrekte antwoorde gee nie.

- Lettergrepe wegneem: Proefpersone kry een woord byvoorbeeld vreeslik, maar die proefpersoon moenie 'lik' sê nie. Die lettergreep wat weggeneem word vorm die woord 'vrees.' Uit die dertien proefpersone was geen proefpersoon in staat om die woord 'vrees' weer te gee nie.

- Begin, middel en eindklank: Proefpersone kry een woord hek waar die begin, middel en eindklank weergegee moet word. Uit die dertien proefpersone kon geen proefpersoon die korrekte antwoord weergee nie.

- Weglaat van klanke: Proefpersone kry een woord ' $m o t$ ' waar die eerste klank weggelaat word en die proefpersoon die oorblywende deel van die woord moet sê. Uit die dertien proefpersone kon geen proefpersoon die korrekte antwoord weergee nie.

- Vervanging van klanke: Die proefpersone kry 'n woord vis, waar die [ə] vervang word met $[a]$ en 'n nuwe woord 'vas' gemaak word. Uit die dertien proefpersone was geen proefpersoon in staat om die woord weer te gee nie. 


\section{Ouditiewe sintese:}

- Voeg woorddele saam: Die proefpersone kry twee woorddele byvoorbeeld hand $+s a k=$ 'handsak' om 'n nuwe woord te vorm. Uit die dertien proefpersone kon geeneen die woorddele saamvoeg om 'n nuwe woord te vorm nie.

- Voeg lettergrepe saam: Die proefpersone kry twee lettergrepe gor $+d y n$ om saam te voeg om 'n nuwe woord 'gordyn' te vorm. Niemand kon die antwoord korrek weergee nie.

- Saamvoeg van klanke om 'n nuwe woord te vorm: Die proefpersone het 'n twee-letter- of drie-letterwoord gekry om 'n woord te vorm byvoorbeeld, [əi]]-[s] is ' $y s$ ' of $[s]-[j n]$ is 'son'. Geeneen kon die antwoord korrek weergee nie.

- Byvoeging van klanke: Die proefpersone kry'n kort woord soos 'is'. Hulle moes 'n klank byvoeg om 'n nuwe woord te vorm soos $[k]$ wat ' $k i s$ ' vorm. Niemand kon die antwoord korrek weergee nie.

- Invoeging van klanke om 'n nuwe woord te vorm: Die proefpersoon kry 'n woord soos ' $k a s$ ' en die woord word verander deur 'n [l] na die [ $k]$ klank in te voeg sodat die nuwe woord 'klas' gevorm word. Niemand kon die antwoord korrek weergee nie.

Die resultaat toon dat die proefpersone baie uitvalle in al die afdelinge van die voortoets oor fonologiese bewustheid in fase een getoon het.

\section{INTERVENSIE VIR FONOLOGIESE BEWUSTHEID}

Die intervensieprogram het begin nadat die voortoets afgehandel is. Die uitvalle van fonologiese bewustheidsontwikkeling wat in die voortoets waargeneem is, is in die intervensieprogram onderrig.

Sewe lesse is volgens die riglyne van bestaande programme aangebied. Die lesse is deur een van die navorsers aangebied. Veldnotas is bygehou om data- insameling te verseker en aanpassings te maak. Tydens die studie is daar tydens elke lesaanbieding van observasie via video-opnames gebruik gemaak om aan te toon of die program wat aangebied word, verandering teweeg bring. Die opdragte op die werkvelle is deur die proefpersone uitgevoer.

Die voltooiing van werkvelle wat deel is van assessering is tydens die navorsing gebruik. Die intervensieprogram het die volgende resultate gelewer: 


\begin{tabular}{|c|c|c|c|}
\hline Werkvel & $\begin{array}{l}\text { Aantal } \\
\text { proefpersone }\end{array}$ & Puntetotaal & Resultaat \\
\hline Woordgeheue & 13 & 8 & $\begin{array}{l}83.3 \% \text { (een proefpersoon) } \\
79.1 \% \text { (een proefpersoon) } \\
66.6 \% \text { (een proefpersoon) } \\
58.3 \% \text { (een proefpersoon) } \\
54.1 \% \text { (een proefpersoon) } \\
50 \% \text { (een proefpersoon) } \\
41.6 \% \text { (een proefpersoon) } \\
37.5 \% \text { (een proefpersoon) } \\
33.3 \% \text { (een proefpersoon) } \\
25 \% \text { (drie proefpersone) } \\
20.8 \% \text { (een proefpersoon) }\end{array}$ \\
\hline Ouditiewe sintese & 13 & 10 & $\begin{array}{l}100 \% \text { (een proefpersoon) } \\
90 \% \text { (een proefpersoon) } \\
80 \% \text { (drie proefpersone) } \\
70 \% \text { (twee proefpersone) } \\
60 \% \text { (een proefpersoon) } \\
50 \% \text { (drie proefpersone) } \\
40 \% \text { (een proefpersoon) } \\
30 \% \text { (een proefpersoon) }\end{array}$ \\
\hline $\begin{array}{lr}\text { Ouditiewe analise } & \text { en } \\
\text { sintese } & \text { met } \\
\text { dubbelkonsonante } & \text { aan } \\
\text { die begin } & \\
\end{array}$ & 11 & 10 & $\begin{array}{l}90 \% \text { (een proefpersoon) } \\
80 \% \text { (een proefpersone) } \\
70 \% \text { (twee proefpersone) } \\
60 \% \text { (drie proefpersoon) } \\
50 \% \text { (twee proefpersone) } \\
40 \% \text { (een proefpersoon) } \\
30 \% \text { (een proefpersoon) }\end{array}$ \\
\hline $\begin{array}{l}\text { Ouditiewe annalise en } \\
\text { sintese met } \\
\text { dubbelkonsonante aan } \\
\text { die einde }\end{array}$ & 13 & 10 & $\begin{array}{l}100 \% \text { (een proefpersoon) } \\
90 \% \text { (een proefpersoon) } \\
80 \% \text { (drie proefpersone) } \\
70 \% \text { (twee proefpersone) } \\
60 \% \text { (een proefpersoon) } \\
50 \% \text { (drie proefpersone) } \\
40 \% \text { (een proefpersoon) } \\
30 \% \text { (een proefpersoon)) }\end{array}$ \\
\hline $\begin{array}{l}\text { Ouditiewe geheue } \\
\text { Werkvel } 1\end{array}$ & 11 & 5 & $\begin{array}{l}100 \% \text { (vyf proefpersone } \\
80 \% \text { (twee proefpersone) } \\
60 \% \text { (drie proefpersone) } \\
20 \% \text { (een proefpersoon) }\end{array}$ \\
\hline $\begin{array}{l}\text { Ouditiewe geheue } \\
\text { Wekvel } 2\end{array}$ & 11 & 10 & $\begin{array}{l}90 \% \text { (drie proefpersone } \\
80 \% \text { (drie proefpersone) } \\
70 \% \text { (twee proefpersone) } \\
60 \% \text { (twee proefpersone) } \\
50 \% \text { (een proefpersoon) }\end{array}$ \\
\hline
\end{tabular}




\begin{tabular}{|l|l|l|l|}
\hline Ouditiewe geheue & 11 & 10 & $\begin{array}{l}50 \% \text { (een proefpersoon) } \\
30 \% \text { (een proefpersoon) } \\
\text { Werkvel 3 }\end{array}$ \\
& & & $\begin{array}{l}20 \% \text { (een proefpersoon) } \\
10 \% \text { (een proefpersoon) } \\
0 \% \text { (sewe proefpersone) }\end{array}$ \\
\hline Rymwoorde & 12 & 8 & $\begin{array}{l}75 \% \text { (drie proefpersone) } \\
62.5 \% \text { (vier proefpersone) } \\
50 \% \text { (een proefpersoon) } \\
\end{array}$ \\
& & & $37.5 \%$ (vier proefpersone) \\
\hline
\end{tabular}

\section{NATOETS VIR FONOLOGIESE BEWUSTHEID}

'n Natoets wat identies as die voortoets is, is deur dertien proefpersone afgelê. Die proefpersone is individueel getoets en veldnotas en optekening is vir elke proefpersoon bygehou. Elke afdeling van die natoets word vervolgens bespreek en die bevindinge word in tabelvorm as 'n direkte vergelyking met die voortoets aangedui:

1. Ouditiewe syfergeheue: Dit het geblyk dat die syfergeheue van die proefpersone in die natoets aansienlik verbeter het.

2. Ouditiewe woordgeheue (verwante woorde): Groot verbeterings in die proefpersone se hantering van verwante woorde het in die natoets plaasgevind.

(Onverwante woorde): Daar is ' $\mathrm{n}$ groot verskil in hierdie afdeling van die voortoets teenoor die resultaat in die natoets. Dramatiese verbeterings in die proefpersone se hantering van onverwante woorde het in die natoets plaasgevind.

\section{Ouditiewe diskriminasie en}

4. rym: In beide aspekte in die voortoetse is geen persentasie bereik nie, terwyl $77 \%$ in die natoets bereik is. Dit is weer eens ' $n$ dramatiese verbetering in die proefpersone se hantering van ouditiewe diskriminasie en rym.

Vergelyking van voortoets en natoets se resultate rakende fonologiese bewustheid:

\begin{tabular}{|l|l|l|}
\hline $\begin{array}{l}\text { Ouditiewe } \\
\text { syfergeheue }\end{array}$ & Voortoets & Natoets \\
\hline $\begin{array}{l}\text { Ouditiewe } \\
\text { woordgeheue } \\
\text { (verwante woorde }\end{array}$ & Nie in staat: $92 \%$ & In staat: $54 \%$ \\
\hline $\begin{array}{l}\text { Onverwante } \\
\text { woorde) }\end{array}$ & Nie in staat: $85 \%$ & In staat: $59 \%$ \\
\hline $\begin{array}{l}\text { Ouditiewe } \\
\text { diskriminasie }\end{array}$ & Nie in staat: $92 \%$ & Nie in staat: $41 \%$ \\
\hline Rym & $\begin{array}{l}\text { In staat: } 0 \% \\
\text { Nie in staat: } 100 \%\end{array}$ & In staat: $99 \%$ \\
& $\begin{array}{l}\text { In staat: } 0 \% \\
\text { Nie in staat: } 100 \%\end{array}$ & $\begin{array}{l}\text { In staat: } 77 \% \\
\text { Nie in staat: } 23 \%\end{array}$ \\
\hline
\end{tabular}

Per Linguam 2015 31(2):53-78 


\section{RESULTATE}

Op grond van die voortoets en natoets se resultate in fase een en fase twee word aangetoon dat daar in die natoetse ' $n$ groot verbetering by leerders wat aan die intervensieprogram van fonologiese en fonemiese bewustheid, asook letter-klankkorrespondering onderwerp is, waargeneem is.

\section{BEVINDINGE}

\section{Bevindinge ten opsigte van fonologiese bewustheid}

Daar is in die voortoets bevind dat die leerders probleme ondervind het met die afdelings van ouditiewe syfergeheue, asook ouditiewe woordgeheue. Uitvalle kom voor wanneer vyfsyfergetalle en verwante en onverwante woorde herroep moes word. Dit dui daarop dat die proefpersone nie wesenlike probleme met die identifisering van die driesyfer- en viersyfer-getalle het nie, maar wel met die vyfsyfergetalle. Die proefgroep kon nie daarin slaag om die ouditiewe woordgeheue met verwante en onverwante woordgroepe weer te gee nie. Die natoets van die afdeling van ouditiewe woordgeheue met die groep verwante woorde kon wel deur die meerderheid proefpersone voltooi word. Die groep woorde wat nie met mekaar verband gehad het nie, is deur die meerderheid proefpersone bemeester. In teenstelling met die voortoets was daar 'n waarneembare verbetering ten opsigte van die afdeling.

Proefpersone kon aanvanklik nie ouditiewe diskriminasie toepas nie. Die hantering van ouditiewe diskriminasie het 'n groot verbetering in die natoets getoon. Rymwoorde was aanvanklik ook moeilik om weer te gee. Die proefgroep kon nie die rymwoord uit vyf woorde identifiseer nie. Rym as 'n afdeling van fonologiese bewustheid het 'n groot uitval getoon in die eerste aktiwiteit met vyf woorde in 'n groep waarvan die woord wat nie rym nie, geïdentifiseer moes word. Die proefpersone het gesukkel om die woord te identifiseer. Die tweede aktiwiteit waar die proefpersoon drie woorde wat soos die woorde in die groep klink moes noem, kon goed bemeester word. In die natoets het daar " $\mathrm{n}$ groot verbetering plaasgevind.

Ouditiewe analise was ook problematies. Geeneen van die proefpersone kon hierdie konsepte verstaan of baasraak in die voortoets nie. 'n Waarneembare verbetering ten opsigte van die ouditiewe ontleding is by hierdie afdeling in die natoets gevind.

Ouditiewe sintese kon deur geen van die proefpersone in die voortoets gedoen word nie. In die natoets is daar verbetering in die afdeling waargeneem.

Proefpersone is nog nie blootgestel aan bovermelde konsepte nie en het dus geen begrip getoon tydens toetsing nie. Die groep woorde was nie op die proefpersoon se vlak nie en hulle het dus swak in dié afdelings gevaar. Proefpersone kom uit 'n taalarm omgewing waar daar geen taal- of leesstimulasie plaasvind nie. Die vermoë om tussen woorde, sinne en klanke te onderskei, verg inoefening en inskerping deur ouer en opvoeder. Alhoewel rym 'n natuurlike ontdekking in taal behoort te wees na blootstelling tuis, is dit duidelik dat hierdie proefgroep geen begrip daarvan toon nie. 


\section{Bevindinge ten opsigte van fonemiese bewustheid}

Daar is 'n merkbare verskil waargeneem tussen die voortoets en die natoets van fonemiese bewustheid in al die afdelings. Die voortoets se resultaat was $75.3 \%$ en die natoets se resultaat het na $96.2 \%$ verbeter. Die behoorlike inskerping van fonologiese en fonemiese bewustheid, asook die blootstelling aan letterklank-korrespondering, het die verdere styging in die verbetering van die natoets regverdig. Die proefpersone het hierdie toets teen 'n vinniger tempo, asook met groter begrip afgelê. Die selfvertroue van hierdie proefgroep het verbeter, asook hulle taalgebruik. Dit blyk dat die fonologiese en fonemiese bewustheidsprogram effektief tydens die onderriggeleenthede toegepas is. Dit lei tot die gevolgtrekking dat fonologiese en fonemiese bewustheid 'n positiewe bydrae tot leessukses by beginnerlesers lewer.

\section{Die vergelyking van die voortoets se resultate van fase een met die van dieselfde natoets in fonemiese bewustheid van fase twee}

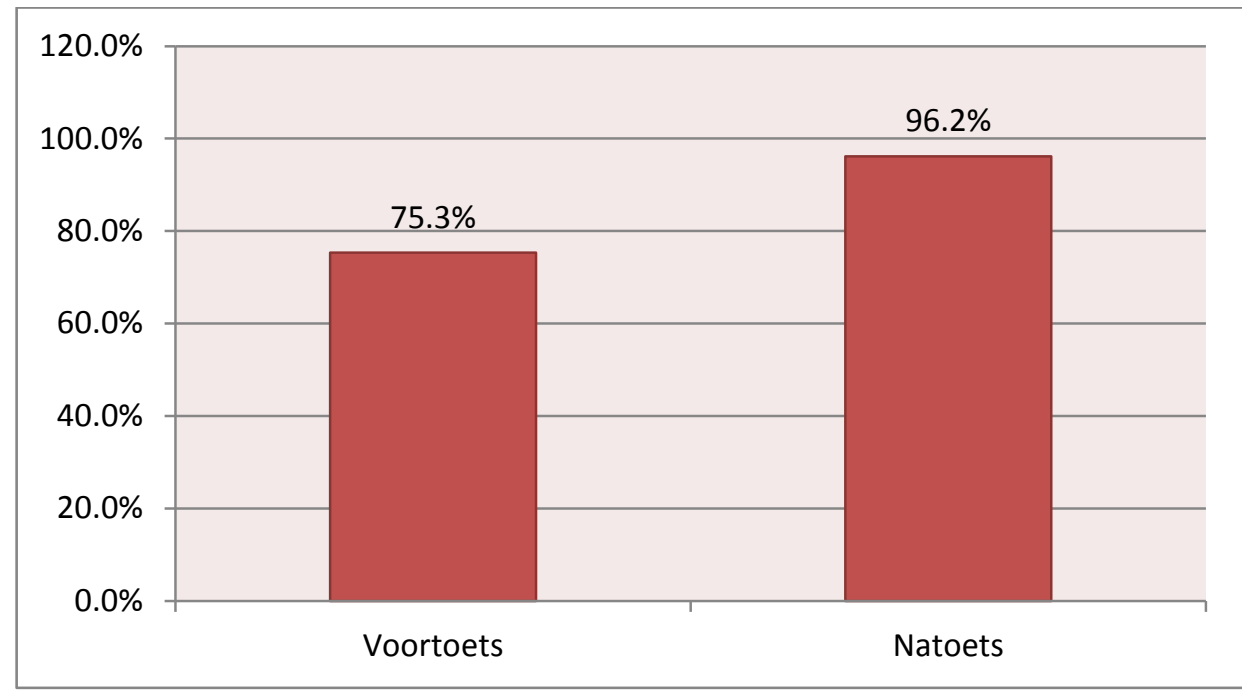

Figuur 1: Vergelyking van die voortoets en natoets van proefpersone ten opsigte van fonemiese bewustheid

\section{AANBEVELINGS}

Fonologiese en fonemiese bewustheid asook letterklank-korrespondering behoort 'n integrale deel te vorm van die gereedmaking vir lees in die aanvangsjaar. Daar moet genoegsame tyd aan die onderrig van fonologiese en fonemiese bewustheid gewy word om sodoende leesonderrig te versterk. Dit sal van groot hulp vir opvoeders wees om 'n voortoets van fonemiese bewustheid by alle graad 1-leerders wat reeds graad R-onderrig ontvang het, te doen. Die vlak van fonemiese bewustheid kan bepaal of die opvoeder met formele leesonderrig kan begin. Graad 1-leerders wat nie die onderrig in graad R ontvang het nie, moet eers onderrig in fonologiese en fonemie se bewustheid ontvang voordat daar na toetsing oorgegaan word. Op grond van die bevindinge van die studie word aanbeveel dat opvoeders 
meer aandag aan die rol van fonologiese en fonemiese bewustheid skenk, aangesien die proefgroep positief gereageer het op die intervensieprogram.

Voorskoolse leerders moet alreeds in die tweede helfte van graad R blootgestel word aan letterklank-korrespondering. Dit is dus baie belangrik dat voorskoolse opleiding verpligtend vir alle leerders moet wees sodat die opvoeder 'n langer tydperk in graad 1 het om aanvangslees en formele lees te onderrig. Na afloop van elke afdelings van fonologiese bewustheid, fonemiese bewustheid en letterklank-korrespondering in graad 1, behoort 'n toets voltooi te word om vas te stel tot op watter vlak die leerder ontwikkel het. Leemtes en uitvalle moet geïdentifiseer word om elke leerder volgens 'n bepaalde leerstyl en leerstrategie te onderrig. Hoë-risiko-leerders wat uitvalle toon, behoort deur middel van 'n intervensieprogram ondersteun te word.

Die volgende lees-elemente behoort (Joubert et al. 2006: 122) tydens die aanbieding van die perseptuele stimuleringsprogram ('n program om graad R- en 1-leerders gereed te maak vir formele leesonderrig) geïntegreer te word:

- Die aanwending van stories, rympies en liedjies

- Die uitbreiding van die woordeskat

- Die ontwikkeling van oogbewegings

- Die ontwikkeling van ouditiewe, visuele en perseptuele waarneming

- Diskriminasie volgens kleur, vorm, grootte en tekstuur

- Terloopslees en

- Bekendstelling van die alfabet (lettername), klanke en vorme van verskillende letters.

Voldoende boeke in die klas om kinders te stimuleer asook prente met woorde teen die muur is noodsaaklik. Die gebruik van woordeboeke, alfabetkaarte en die 100-boekprojek van die Departement van Onderwys kan doeltreffend in die klaskamer gebruik word om geletterdheid te bevorder. Die NKABV gee ook duidelike riglyne vir voorgestelde tekste en hulpmiddels wat gebruik word soos CD's of bande met stories en luisteroefeninge, prent- en woordraaisels en -speletjies. NKABV (2011: 193). Klanksensitiwiteit en foneembewussyn kan bevorder word deur die kind te laat luister na talle rympies, stories, gediggies en liedjies, deur voorlees- en selflees-geleenthede tot drie keer per dag te organiseer. Die onderrig van klanke, 15 minute per dag vir vier dae, is ook deel van die Huistaalprogram in onderrig (DvBO, 2011: 11-12). Sinvolle gesprekke met kleuters om goeie taalmodelle te voorsien deur die kleuter te omring met leesstof in alle vorme op verskillende leesvlakke kan ook 'n positiewe bydrae lewer (Le Roux 1995: 3; Morrow 1997: 243).

\section{Aanbevelings ten opsigte van die kurrikulum}

Die kurrikulum behoort aangepas te word om die nodige vaslegging en inskerping van letter klankkorrespondering te bemeester. Daar behoort meer tyd aan die kurrikulum vir geletterdheid gewy te word en die rooster vir geletterdheid behoort aangepas te word om voorsiening te mak vir die onderrig van fonemiese, fonologiese en letterklankkorrespondering wat as basis vir suksesvolle lees dien. Die gebruik van die beskikbare rekenaarsagtewareprogramme, byvoorbeeld CAMI lees en CAMI diagnosties behoort in die kurrikulum ingewerk te word om leessukses te bevorder. Duidelike riglyne moet in die kurrikulum neergelê word sodat vaardighede makliker bereik kan word. Leerprogramme soos 
die "Grondslag vir Leer" wat deur die Nasionale Departement van Onderwys aan skole bekendgestel is, moet deeglik onderrig word.

\section{Aanbevelings ten opsigte van opvoeders}

Opvoeders kan deeglik tydens onderwyseropleiding / indiensopleidingsessies opgelei word om fonologiese en fonemiese bewustheid, asook letterklank-korrespondering as 'n integrale deel van Geletterdheid en taal oor die kurrikulum aan te bied, byvoorbeeld tydens Visuele en Uitvoerende kunste (musiek, drama, kuns), Liggaamlike Opvoeding, Wiskunde en Lewensvaardigheid.

Linnea, Nunes en Ehri (2004: 113) benadruk dat fonologiese en fonemiese bewustheid as die beste voorspellers vir leessukses beskou kan word. Die twee hoofboustene, naamlik fonemiese bewustheid en klanke speel ' $\mathrm{n}$ kardinale rol by ontwikkeling van geletterdheid.

\section{SLOTPERSPEKTIEF}

Alhoewel die gebalanseerde leesmetode deur die Onderwysdepartement aanbeveel word, behoort opvoeders leerders in 'n taalarm omgewing te help om tegnieke en strategieë te ontdek wat hulle sal help om die 'kode' van skrif te ontsluit. Dit kan onder andere bereik word deur middel van die ontwikkeling van woordherkennings- en begripsvaardighede. Klanke in konteks is belangrik, lees moet onderrig word en verskillende leesbenaderings behoort gevolg te word.

\section{BRONNELYS}

ADAMS, M.J. 1990. Beginning to Read. Thinking and Learning about Print. Cambridge, MA: The MIT Press.

BANDURA, A.1997. Social learning theory. Englewood Cliffs, NJ: Prentice Hall.

BOTHA, D. 2008. Read Educational Trust: a Balanced Language Programme Handbook. Johannesburg: Edcon.

BRADLEY, L. \& P.E. BRYANT. 1985. Categorising sounds and learning to read: A causal connection. Nature, 301(5899): 419-421.

DEMONT, E. \& CROMBERT, J.E. 1996. Phonological awareness as a predictor of recording skills and syntactic awareness as a predictor of comprehension skills. British Journal of Education Psychology, 66(3): 315-332, September.

DEPARTEMENT VAN BASIESE ONDERWYS. 2008. Grondslag vir Leer. Pretoria: Staatsdrukker.

DEPARTEMENT VAN BASIESE ONDERWYS. 2011. Nasionale Kurrikulum- en Assesseringsbeleidsverklaring. Graad 1-3 (Skole). Tale. Afrikaans Huistaal. Pretoria: Staatsdrukker.

ERICSON, L. \& JULIEBÖ, M.F. 2000. The phonological Handbook for Kindergarten and Primary Teachers. Canada: Christian A. Kempers.

GRIFFITH, P., J. KLESIUS \& J. KROMEREY. 1992. The effect of phonemic awareness on the literacy development of first grade children in a traditional or whole language classroom. Journal of Research in Childhood Education, 6(2): 85-92.

GROVÉ, M.C. \& HAUPTFLEISCH, H.M. 1992. Trapklippies: 'n Program vir skoolgereedheid Deel 2 Onderwyserhandleiding: Pretoria: De Jager-Haum Publishers. 
JOUBERT, I., M. BESTER \& E. MEYER. 2006. Geletterdheid in die grondslagfase. Pretoria: Van Schaik Uitgewers.

LE ROUX, M. 1995. Leesgereed - Leefgereed. Klasgids/ In NALIN Uitgewers, 30(2): 2-4.

LIBERMAN, I.Y., D SHANKWEILER, F.W. FISCHER \& B. CARTER. 1974. Explicit syllable and phoneme segmentation in the young child. Journal of Experimental Child Psychology, 18(2): 201-212.

LINNEA, C. EHRI, L. \& NUNES, S. 2004. The Role of Phonemic Awareness in Learning to Read. 3rd ed. USA: Newark.

MARTHINUSSEN, P.J.2012. Die belangrikheid van fonologiese en fonemiese bewustheid in aanvangslees by graad 1-leerders in " $n$ taalarm omgewing. Ongepubliseerde Magistertesis. Kaapse Skiereilandse Universiteit van Tegnologie.

MERCER, C.D. 1997. Students with learning disabilities 5th ed. Colombus: Charles E. Merril

MCLEOD, S. A. (2011). Bandura - Social Learning Theory. Beskikbaar http://www.simplypsychology.org/bandura.html [Geraadpleeg: 10 September 2013]

MORROW, L.M. 1997. Literacy development in the early years. Needham Heights: Allyn \& Bacon.

NATIONAL READING PANEL. 2002. Report of the National Reading Panel: Teaching Children to Read. Beskikbaaar by http://www.nichd.nih.gov [Geraadpleeg: 11 Februarie 2004].

PEPLER, A. 2005. Die ontwikkeling van 'n geletterdheidsprogram vir Graad R-leerders. Ongepubliseerde PhD-proefskrif. Stellenbosch: Universiteit van Stellenbosch.

PHILLIPS, B.M., J.C. MENCHETTI \& C.J. LONIGAN. 2008. Topics in early childhood special education. Successful Phonological Awareness instruction with Preschool Children: Lessons from the Classroom, 28(1): 3-15.

STAHL, S.A.1992. Saying the "p" word: Nine guidelines for exemplary phonics instruction. The Reading Teacher, 45(8): 618-625, April.

STANOVICH, K.E. 1993. Romance and reality. The Reading Teacher, 47(4): 280--88.

STANOVICH, K.E., A.E. CUNNINGHAM \& B.B. CRAMER. 1984. Assessing phonological awareness in kindergarten children: Issues of task comparability. Journal of Experimental Child Psychology, 38(2): 175-190.

SNIDER, V.E. 1995. A primer on phonemic awareness: what it is, why it's so important and how to teach it. School Psychology Review 24(3): 443-455, March.

VENTER, A. 2007. Die ontwerp, implementering en evaluering van 'n multisensoriese leesprogram vir graad 3-leerders. Ongepubliseerde PhD-proefskrif, Universiteit van die Vrystaat.

VYGOTSKY, L.S. 1978. Mind in society: The development of higher psychological processes. Cambridge: Harvard University Press.

WARMINGTON, M. \& C. HULME. 2012. Phoneme Awareness, Visual-Verbal PairedAssociate Learning, and Rapid Automatized Naming as Predictors of Individual Differences in Reading Ability, Scientific Studies of Reading,16(1): 45-62.

YOPP, H.K. \& R.H. YOPP. 2000. Supporting phonemic awareness development in the classroom. The Reading Teacher, 54(2): 130--430.

\section{BIOGRAFIESE NOTA}

Patricia Joyce Marthinussen is vakadviseur by die Kaapse Wynland Onderwysdistrik Worcester waar sy in grondslagfase spesialiseer om opvoeders te adviseer in die toepassing 
van die kurrikulum in Graad R-3. Haar navorsing sluit die belangrikheid van fonologiese en fonemiese bewustheid in aanvangslees by graad 1- leerders in ' $n$ taalarm omgewing in.

E-pos: patsy.marthinussen@westerncape.gov.za

Michele van der Merwe is lektor by die Fakulteit van Opvoedkunde aan die Universiteit van Stellenbosch waar sy Afrikaans op voorgraadse en nagraadse vlak doseer. Sy spesialiseer in leksikografie, veral opvoedkundige leksikografie. Haar navorsing sluit die onderrig van woordeboek- en taalvaardighede, die skep van 'n woordeboekkultuur in skole, asook die gebruik van (vak)woordeboeke via tegnologie in.

E-pos: michelevdm@sun.ac.za 
Bylaag A: Voortoets / Natoets vir Fonologiese bewustheid

\begin{tabular}{|c|c|}
\hline \multicolumn{2}{|c|}{$\begin{array}{l}\text { WESKUS-WYNLAND OBOS: } \\
\text { WEST COAST WINELANDS }\end{array}$} \\
\hline \multicolumn{2}{|c|}{ SIFTINGSTOETS VIR OUDITIEWE PERSEPSIE } \\
\hline \multicolumn{2}{|c|}{ Biografiese Besonderhede } \\
\hline Van: & Voorname: \\
\hline Geboortedatum: & Duderdom: .........jr. / ........mnd. \\
\hline \multicolumn{2}{|c|}{ Skool: $\quad$ Graad: } \\
\hline \multicolumn{2}{|c|}{ 1. OUDITIEWE SYFERGEHEUE } \\
\hline \multicolumn{2}{|c|}{$\begin{array}{l}\text { Leerkrag lees die getalle stadig en duidelik. Die leerder moet die reeks getalle korrek kan } \\
\text { herhaal. Begin by } 3 \text {, dan } 4 \text { en dan } 5 \text {. Leerders kry slegs een kans by elk van die } \\
\text { getalreekse. }\end{array}$} \\
\hline \multicolumn{2}{|c|}{\begin{tabular}{l|l}
647 & $\cdot 37692$ \\
\end{tabular}} \\
\hline \multicolumn{2}{|c|}{\begin{tabular}{ll|l}
218 & 34 & $\cdot 28415$ \\
\end{tabular}} \\
\hline \\
\hline & \begin{tabular}{l|l}
-8315 & $\cdot 428315$ \\
\end{tabular} \\
\hline \multicolumn{2}{|c|}{ 2. OUDITIEWE WOORDGEHEUE } \\
\hline \multicolumn{2}{|c|}{$\begin{array}{l}\text { Leerkrag lees die woorde stadig en duidelik. Die leerder moet die reeks woorde korrek kan } \\
\text { herhaal. Begin by } 3 \text {, dan } 4 \text { en dan } 5 \text {. Leerders kry slegs een kans by elk van die woordreekse. }\end{array}$} \\
\hline Verwante woorde & Onverwante woorde \\
\hline - vark, koei, perd & - hek, loop, jas \\
\hline - rooi, geel, blou, swart & - vis, sop, kas, rek \\
\hline - appel, peer, lemoen, piesang, vy & - vet, bos, nek, wol, beer \\
\hline \multicolumn{2}{|c|}{ 3. OUDITIEWE DISKRIMINASIE } \\
\hline \multicolumn{2}{|c|}{$\begin{array}{l}\text { Leerders lees die woordpare stadig en duidelik sonder dat die leerder sy/haar mond kan sien. Die } \\
\text { leerder moet kan identifiseer of die woorde dieselfde is of nie. Maak vooraf seker dat die leerder } \\
\text { die konsepte dieselfde/verskillend en eenders/anders verstaan. }\end{array}$} \\
\hline - nies - nies & - red-red \\
\hline - boot-poot & - kies-koes \\
\hline - muis - huis & - deur-dier \\
\hline - pot-pos & - dam-dan \\
\hline - sap-sap & - vis - wis \\
\hline \multicolumn{2}{|c|}{ 4. RYM } \\
\hline \multicolumn{2}{|c|}{$\begin{array}{l}\text { Rymdeteksie: Leerkrag vra: } \\
\text { "Watter woord klink nie soos die ander woorde nie?" }\end{array}$} \\
\hline \multicolumn{2}{|c|}{ - muur, suur, vuur, hout, duur } \\
\hline \multicolumn{2}{|l|}{ - lees, muis, lees, bees, gees } \\
\hline \multicolumn{2}{|l|}{$\begin{array}{l}\text { Rymproduksie: Leerkrag vra: } \\
\text { "Noem woorde wat amper klink soos." }\end{array}$} \\
\hline - kos, los, mos, (bos, pos, klos) & \\
\hline - bad, kat, rat, (vat, mat, skat) & \\
\hline
\end{tabular}




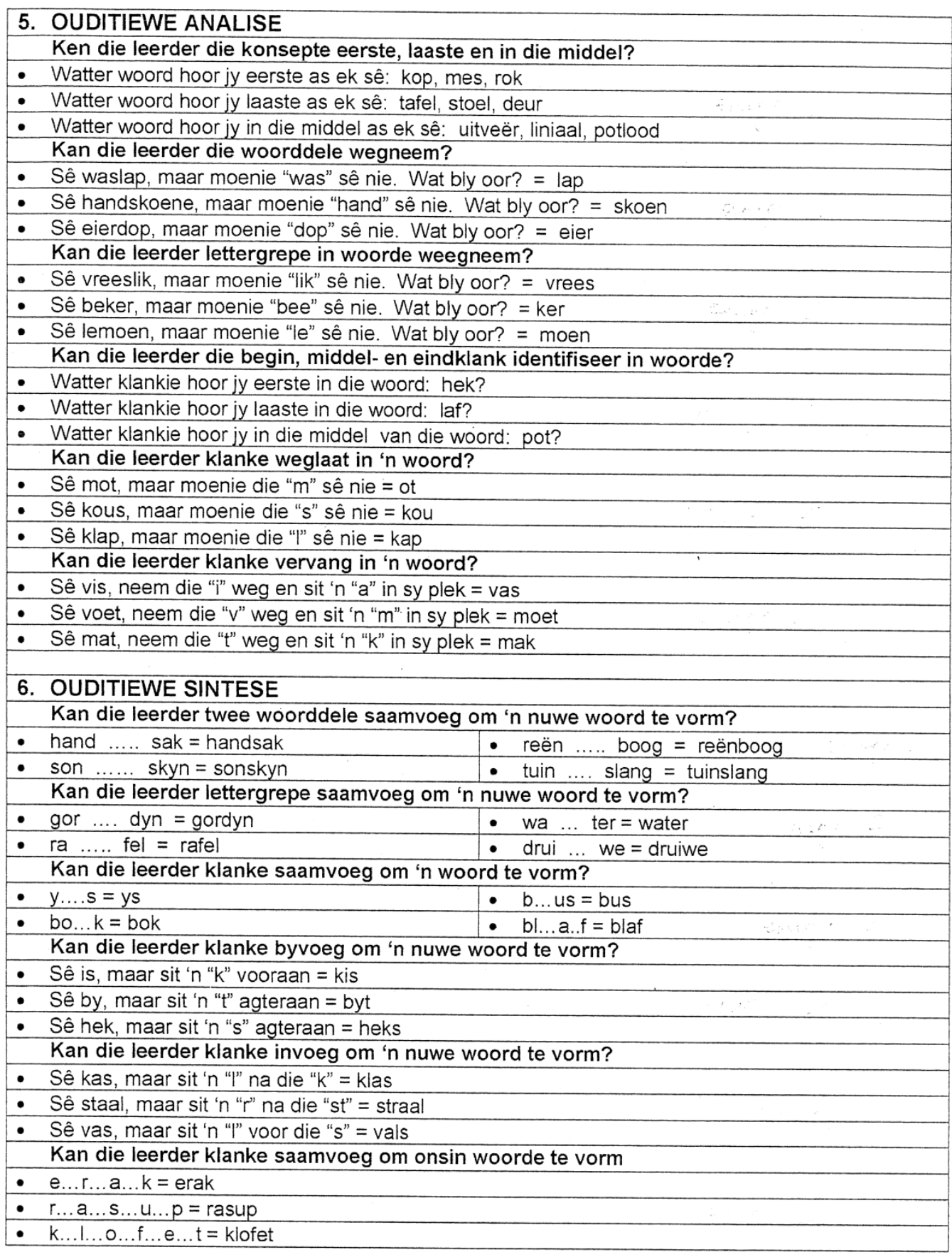




\section{Bylaag B: Die Yopp-Singertoets vir Fonemiese Segmentasie}

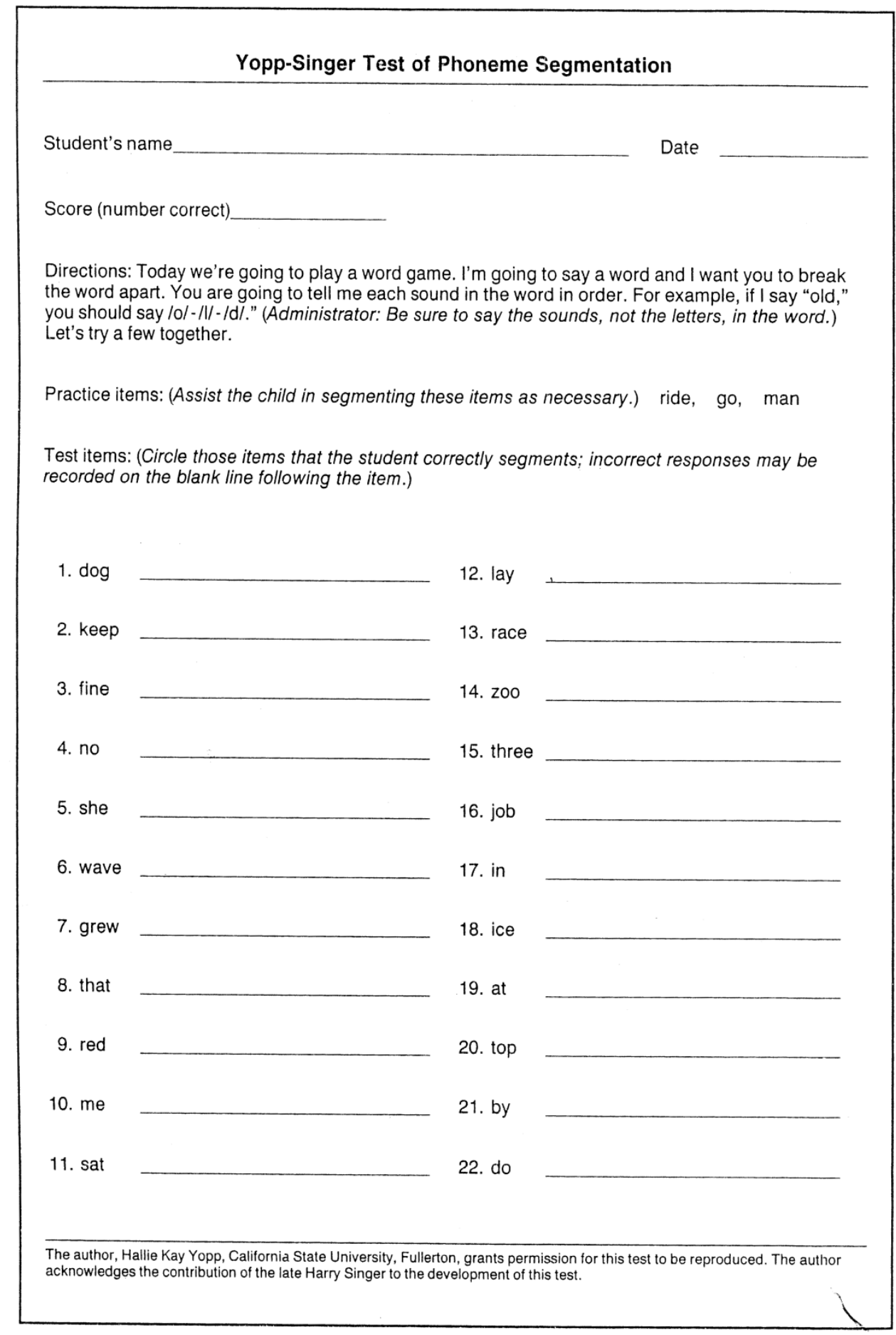

22 The Reading Teacher Vol. 49, No. 1 September 1995 


\section{Bylaag C}

\section{Die intervensieprogram}

Leerders uit ' $n$ taalarm omgewing met geen graad R-onderrig nie word vir hierdie studie gebruik. Die ouderdom van hierdie leerders wissel vanaf vyf jaar en ses maande tot vyf jaar en nege maande. Dertien leerders uit 'n klas van veertig word vir twintig minute op 'n Dinsdag, Woensdag en Donderdag onttrek, om die aksienavorsing te onderneem.

Die volgende metode word in die aanbieding van die lesse toegepas: In die eerste ses weke word daar klem gelê op die fonologiese ontwikkeling. Verskillende leerstyle en onderrigstrategieë word gebruik om die begrip van fonologiese bewustheid te ontwikkel. 'n Voortoets word afgeneem waarin die leerders se begrip van fonologiese bewustheid vasgestel word.

$\mathrm{Na}$ aanleiding van die uitvalle in die voortoets word die volgende lesse beplan om aangebied te word om die fonologiese bewustheid te ontwikkel.

In die Geletterdheids- leerarea van die NKV word uitkoms een, naamlik die LUISTERkomponent, beklemtoon. Die assesseringstandaarde vir hierdie komponent in graad $\mathrm{R}$ en graad 1 word behandel met die klem op assesseringstandaard vier by graad $\mathrm{R}$ en assesseringstandaard ses by graad 1. Refleksie op lesaanbieding word telkens verskaf.

\section{Fase Een: fonologiese bewustheid}

Intervensie om fonologiese bewustheid te ontwikkel

Die volgende lesse word aangebied, volgens riglyne van bestaande programme. Die lesse word deur die navorser aangebied.

\section{Les 1: Tema: My liggaam}

In hierdie les sit leerders op die mat. 'n Ouditiewe oefening word aan die leerders gegee. Leerders kry die geleentheid om na woorde te luister. Die opvoeder vra: "Klink die woorde dieselfde of verskillend?" Leerders word gevra om hul duim op te lig as dit dieselfde klink en af te wys as dit verskillend klink, byvoorbeeld:

rooi - rooi

rooi - geel

geel - blou

groen - groen

'n Eggo-speletjie word nou gespeel. Die opvoeder sê: "Ek gaan nou twee sinne sê. Wanneer die sinne dieselfde klink, wys duime op, verskillend, wys duime af."

Byvoorbeeld:

Sin een: "Dit is 'n rooi sirkel."

Sin twee "Dit is 'n rooi sirkel."

Sin een: "Die twee rooi sirkels lyk dieselfde."

Sin twee: "Die twee rooi sirkels lyk verskillend." 
Sin een: "Blou is 'n mooi kleur."

Sin twee: "Blou is 'n mooi kleur."

Leerders kan ook die speletjie speel. Die klasgroepe luister. 'n Kasset met vervoergeluide word gespeel. Leerders identifiseer die geluide wat deur die verskillende vervoermiddels gemaak word. Aan die einde van die les luister die leerders na die volgende rympies wat deur die opvoeder opgesê word:

Duimpie, duimpie se maat, Langeraat, Fielafooi, Pieps in die kooi.

Kyk uit! Ruik uit!

Hap - hap - hap!

Wielie, wielie walie,

Die aap ry op die balie,

Tjoef, tjaf, daar val hy af, wielie wielie walie.

Klippertjie, klappertjie

Klap, klap, klap

Mondjie happertjie

Hap-hap-hap!

(Leerders luister slegs na die rympies)

Veldnotas en Waarneming/Refleksie word tydens en na afloop van die les aangeteken, Waarneming/Refleksie tydens lesse een tot ses

Waarneming/Refleksie Les 1

Leerders geniet die les, want dit is duidelik dat hulle hulself vereenselwig met die tema van die les, asook die eggo-speletjie wat gespeel is. Leerders hou van speletjies, want dit behou hul aandag.

Daar is nog baie verwarring met die begrippe 'eenders' en 'verskillend'. Dit is 'n konsep wat nog vasgelê moet word. Die rympies, liedjies en luisteroefeninge was genotvol, aangesien dit binne die kind se ervaringsveld is. Hulle onthou nie die opdrag nie. Die formele opset in die klas speel ook 'n belangrike rol omdat baie van hierdie leerders jonk is en nog in 'n speelopset wil funksioneer. Uit die dertien leerders kon slegs twee reageer op die vrae terwyl die res nie kon saamwerk deur die verlangde reaksie te toon nie.

Les 2: Tema: My liggaam

In hierdie les sit leerders op die mat.

Die volgende rympie word aan die leerders opgesê:

Laat die voetjies trap, trap, trap

Laat die handjies klap, klap, klap

Pasop vir jou! Pasop vir jou!

Of jy kruip onder die taaibostou!

Ienkel, dienkel, dalie - kind 
Hardloop soos die wilde wind

Hier gedraai en daar geswaai

En binne - in my hart gewaai.

Ouditiewe woordgeheue:

Die opvoeder lees die volgende woorde stadig en duidelik. Die leerder moet die woorde korrek herhaal na een keer se luister. Die opvoeder begin by drie woorde, dan vier woorde en dan vyf woorde. Woorde wat verwant is aanmekaar, word eerste gelees. Daarna word woorde wat onverwant is gelees.

Verwante woorde:

Onverwante woorde:

Vark, koei, perd

kop, motor, sand

Rooi, geel, blou, swart

Appel, peer, lemoen, piesang, vy

vis, sop, kas, rek

vet, bos, nek, wol, beer

Rym:

Die opvoeder verduidelik die betekenis van rym. Dit is woorde wat dieselfde klink soos byvoorbeeld: muur, suur, duur ; lees, bees gees.

Leerders luister na woorde wat rym en identifiseer rym deur middel van 'n speletjie.

Rymdeteksie:

Die opvoeder vra: "Watter woord klink nie soos die ander woorde nie?" kos, los, bos, wil Rymproduksie:

Die opvoeder vra: "Noem woorde wat amper klink soos: kos, los, mos.

'n Kasset met geluide van diere word aan leerders gespeel. Leerders identifiseer geluide.

Afsluiting: Lied: Skoppelmaai (sing)

Waarneming/Refleksie en veldnotas word aangeteken.

Leerders ontvang 'n werkvel met prente. Werkvel 1 (Bylaag D).

Instruksie: Kies 'n prent wat met die beklemtoonde woord rym.

Vir data-doeleindes sal die werkvel beskikbaar wees om data te analiseer.

Waarneming/Refleksie Les 2

Woordgeheue:

Leerders toon belangstelling in die les, want die woorde wat hulle moes weergee, is bekend aan hulle en hulle kon hulself daarmee assossieer omdat die woordeskat op hul vlak is. Leerders kon die drie woorde wat verwant is aanmekaar, in die volgorde onthou omdat dit bekende woorde vir die leerders is. Hulle sukkel om die drie woorde wat nie verwant aanmekaar is nie te onthou omdat dit nie korreleer met mekaar nie en dit ook nie 'n eenheid vorm nie. Leerders kon nie vier woorde in die regte volgorde weergee nie. Die onthouvermoë is nog nie goed ontwikkel nie en die vaardigheid om te luister, is in 'n ontwikkelingsoproses. Slegs een leerder het daarin geslaag om die woorde korrek weer te gee. Met die vyf woorde het dit nog moeiliker gegaan omdat dit meer woorde was en die onthouvermoë nog nie op peil is nie. Slegs een kind kon die woorde korrek weergee.

Die luisteroefening van dieregeluide op die kasset het leerders geïnteresseer, want die dieregeluide is bekend aan hulle. Alhoewel die voëlgeluid aan leerders bekend is, kon hulle dit egter nie identifiseer nie.

Tydens die aanbieding van die begrip rym, het leerders dit moeilik gevind om die begrip te verstaan. Soos wat die les ontwikkel het, kon die leerders sekere begrippe soos rymdeteksie 
en rymproduksie verstaan. By die aanleer van die begrip, rymdeteksie, was daar vyf van die leerders wat dit moeilik gevind het om die woord wat nie dieselfde klink nie, te identifiseer. Die rede vir hierdie afwyking is dat dit'n ingewikkelde denkproses is wat verwarrend kan wees wanneer die woorde weergegee moet word. Leerders het nog nie tot die vlak ontwikkel om die proses te verstaan nie. Die begrip van rymproduksie was ook moeilik omdat leerders se woordeskat nog baie beperk is en hulle nie maklik die woorde wat dieselfde as die groep wat gesê is, kon weergee nie.

\section{Fase twee: fonemiese bewustheid}

Intervensie om fonemiese bewustheid met letter-klankkorrespondering te ontwikkel Die volgende lesse word onderrig om letter- klankkorrespondering vas te lê:.

Les 1

Aanleer van letter-klankkorrespondering [k], [э] en [m] Stap 1: Opvoeder wys woordflitskaart 'kom ' aan leerders. Hulle lees dit.

Stap 2: Opvoeder sê: "In hierdie woord is daar drie letters." Elke letter het 'n werkie om te doen. Elkeen het 'n klank en die klankies saam sê die woord 'kom'. Luister nou mooi as ek die woord sê, dan sê julle vir my wat die eerste klankie is." Opvoeder lê klem op die [k]. "Wat het julle nou eerste gehoor?" (Wanneer die leerders dit nou reg antwoord, word die letter [k] op die skryfbord geskryf).

"Ja, dis 'n sagte $[\mathrm{k}]$ en nie 'n harde $[\mathrm{k}]$ nie - sê almal dit nou saam.

Wat moet nou kom?" (Die opvoeder sê die hele woord weer, maar lê nadruk op die [э] klank. Die leerders luister en sê watter klank dit is. Die opvoeder skryf dit op die skryfbord). "Nou ken ons al twee van die klankies. Kom ons sê die klankies weer." (Die twee klanke word herhaal. Die [m] aan die einde van die woord word op dieselfde wyse behandel). Stap 3: Die drie flitskaarte met die enkel letters word uitgestal. "Wie kan met hierdie drie kaartjies die woord 'kom' vir my bou?" Die leerders neem beurte om met die oorspronklike flitskaart as leidraad die drie letters te kom rangskik. Nou herhaal almal die klanke en sê die woord [k]-[ o]-[m], 'kom'.

Afsluiting:

Leerders kry die geleentheid om die klanke [k], [ว] en [m] te voel met rubbervorms. 'n Klankkaart met prente van woorde wat met die drie klanke begin, word aan die leerders gewys. Leerders identifiseer die prente en assossieer dit met die klank wat hulle geleer het.

\section{Waarneming/Refleksie Les 1}

Dit is duidelik dat die leerders goeie begrip toon ten opsigte van die klanke wat hul hoor en wat tydens die fonologiese proses behandel is. Tien van die twaalf leerders kon [k], [o] en [m] identifiseer en kon dit in konteks van die woord 'kom' weergee. Leerders kon die letterklanke gebruik om hul eie woord 'kom ' te bou. Slegs twee van die leerders het 'mok' gebou. Dit is duidelik dat leerders dit geniet om die letterklanke van rubber te voel en so word hul vaslegging in die vorming van die klank ingeskerp. Leerders maak gebruik van hul sintuiglike gewaarwording van 'voel' wat gebruik word om letterklank-vaslegging te doen. Leerders kon die letterklankkaart met prente goed beantwoord en met die prente wat die letterklank voorstel, identifiseer.

Les 2

Per Linguam 2015 31(2):53-78 
Vaslegging van die klanke [k], [o] en [m]

In hierdie les word stappe 1, 2 en 3 van die vorige les hersien. Leerders kry kans om die klanke [k], [o] en [m] te bou met pypskoonmakers. 'n Werkvel met die drie klanke word aan leerders gegee. Leerders identifiseer die klanke wat aangeleer is.

Waarneming/Refleksie Les 2

Leerders kon hul eie woord met pypskoonmakers bou. Slegs vier van die leerders sukkel om $[\mathrm{k}]$ en $[\mathrm{m}]$ te vorm omdat daar van rigting verander word om $[\mathrm{k}]$ en $[\mathrm{m}]$ te vorm. Dit is maklik om die [ $\mathrm{\jmath}$ te vorm omdat dit slegs in een rigting gevorm word. Die leerders wat dit kon bemeester, het saam die woord 'kom ' gevorm met hul pypskoonmakers. Die werkvel waar leerders die $[\mathrm{m}]$ moes identifiseer, is deur die meeste leerders voltooi. Slegs drie van die leerders kon dit nie met gemak voltooi nie. 


\section{Bylaag D: Werkvel 2 - Woordgeheue}

OPDRAG: Kanjy onthou watter woorde ek sê? Trek kruisies deur die regte prentjies.

1. druiwe,appel, perske

2. vark, kat, perd

3. hamer, kwas, tang, saag
4. bus, vllegtulg, fiets, boot

5. oor, hand, neus, arm, ken

6. bal, pop, wa, vlieër, tol

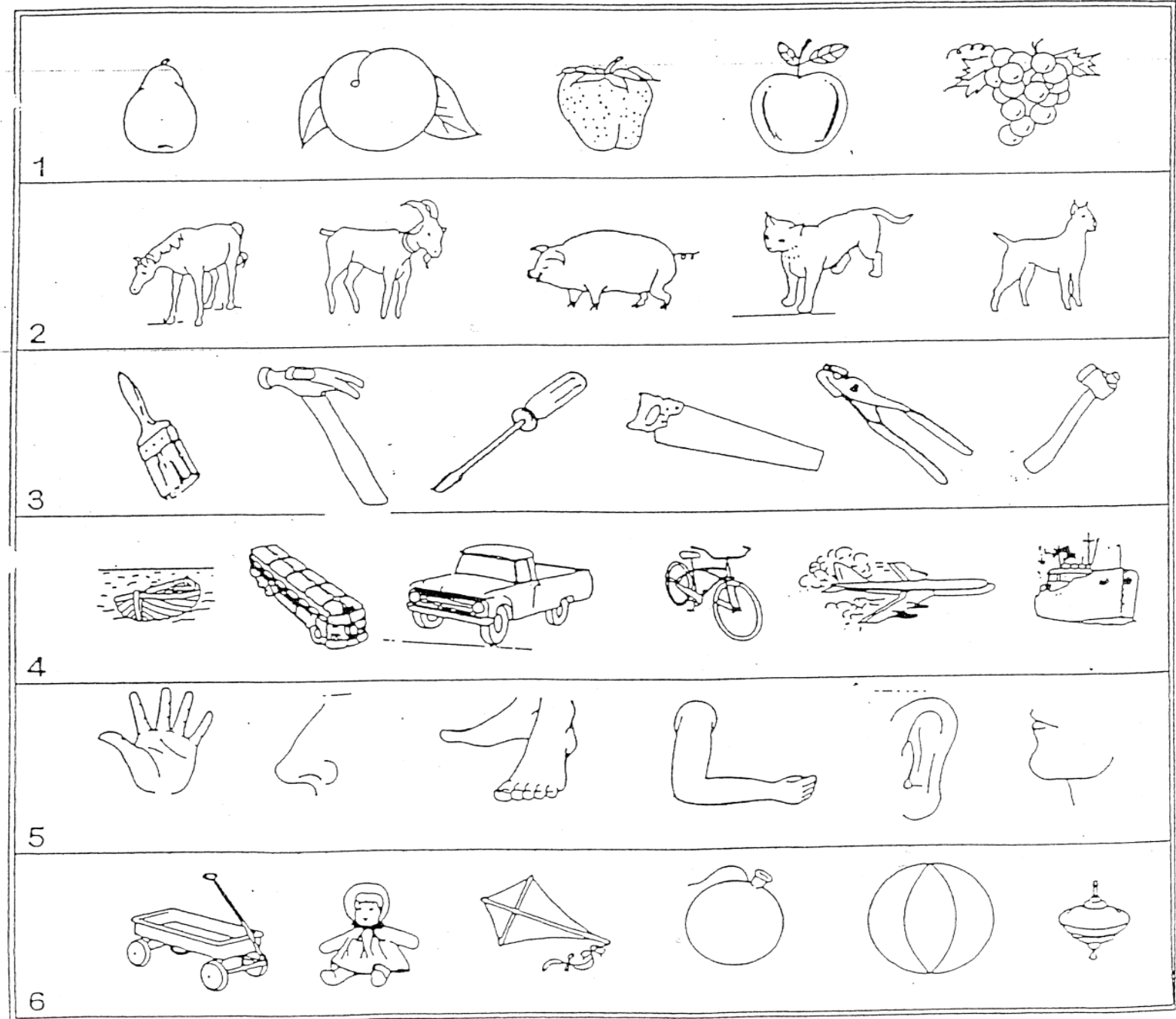


Bylaag E: Werkvelle: Intervensieprogram/Werkvelle vir letterklank-korrespondering
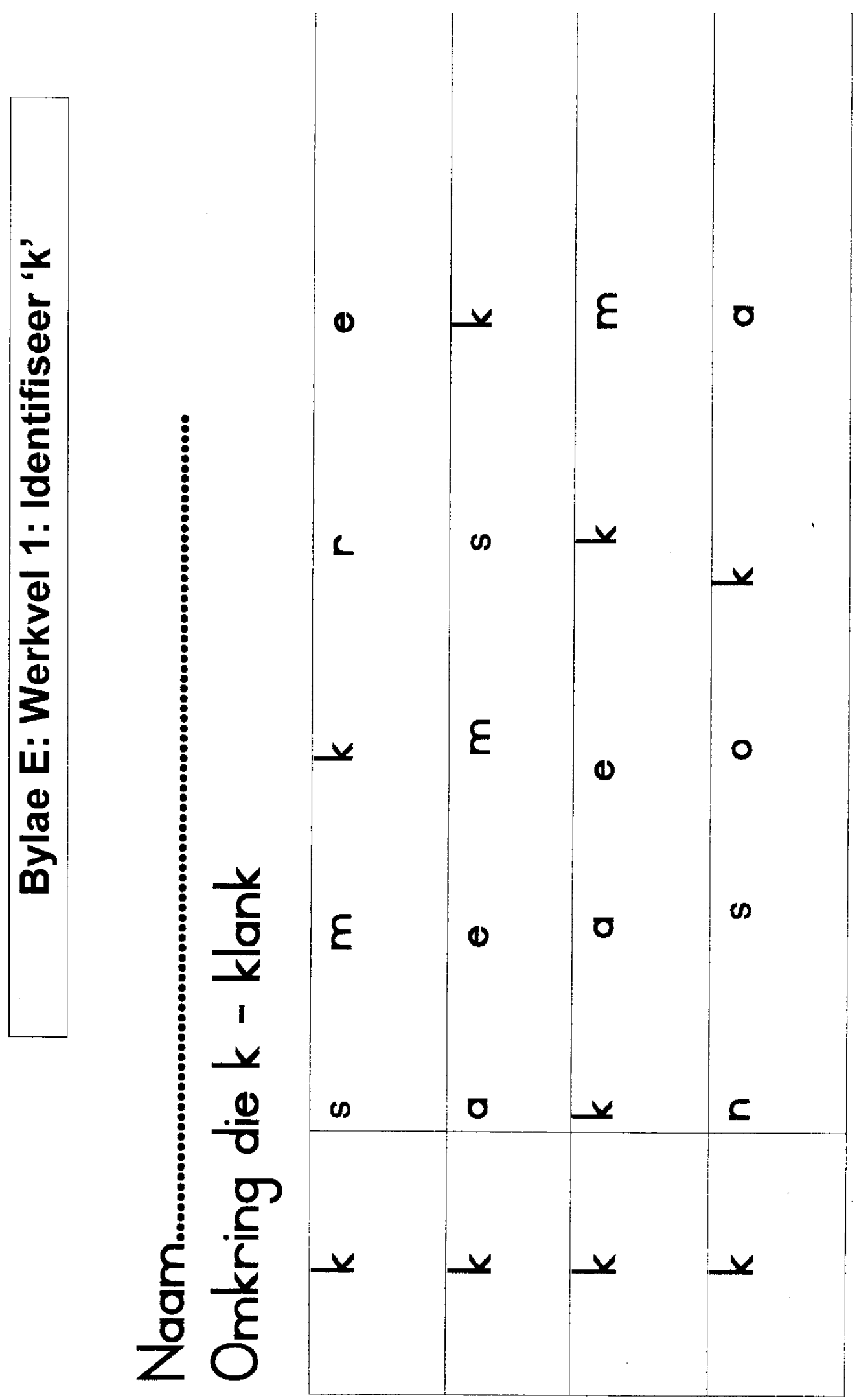